\title{
The Course of Performance Doctrine in Commercial Contracts: An Empirical Analysis
}

Uri Benoliel

Follow this and additional works at: https://via.library.depaul.edu/law-review

Part of the Law Commons

\section{Recommended Citation}

Uri Benoliel, The Course of Performance Doctrine in Commercial Contracts: An Empirical Analysis, 68 DePaul L. Rev. (2019)

Available at: https://via.library.depaul.edu/law-review/vol68/iss1/2

This Article is brought to you for free and open access by the College of Law at Digital Commons@DePaul. It has been accepted for inclusion in DePaul Law Review by an authorized editor of Digital Commons@DePaul. For more information, please contact digitalservices@depaul.edu. 


\title{
THE COURSE OF PERFORMANCE DOCTRINE IN COMMERCIAL CONTRACTS: AN EMPIRICAL ANALYSIS
}

\author{
Uri Benoliel*
}

\section{Contents}

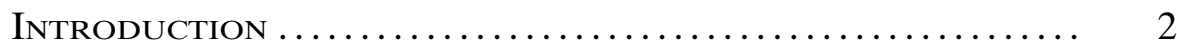

I. The Course of Performance Doctrine-An

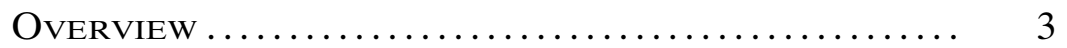

II. The Theoretical Debate over Course of

III. The Empirical Test ......................... 13

A. No-Oral-Modification Clause-A Brief Overview ... 13

B. The Theoretical Hypotheses ................... 15

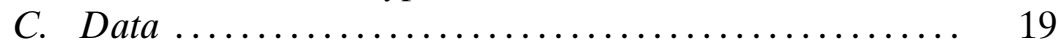

D. Methodology ......................... 21

E. Results ............................... 22

IV. Discussion and Normative Implications ........ 24

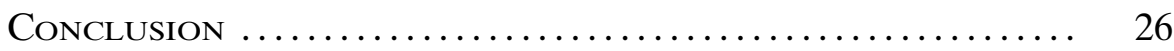

The course of performance doctrine plays a significant role in American contract law. The theoretical debate over the doctrine revolves around one central question-What is the intention of the parties regarding the application of the doctrine? Proponents of the doctrine believe that its application reflects the actual intention of the parties. In contrast, opponents of the doctrine believe that the doctrine stands contrary to the intention of the parties.

Despite the widespread debate over the course of performance doctrine, there are no quantitative empirical studies aimed at directly exposing the parties' true intention about the doctrine. This Article aims to fill this research void by empirically analyzing actual anti-course of performance clauses in commercial contracts. By examining 1,550 commercial contracts that have been disclosed to the Securities and

* Faculty of Law, College of Law \& Business. J.S.D. (UC Berkeley); L.L.M. (Columbia University). I am grateful to Oren Bar-GilI, Samuel Becher, Lisa Bernstein, Hanoch Dagan, Alon Harel, Robert Hillman, Ariel Porat, and Tal Zarsky for invaluable comments on earlier drafts of this article. 
Exchange Commission, this Article finds that a clear majority (80.06\%) of contracts include an anti-course of performance clause. In addition, the results of this study indicate that the anti-course of performance clauses included in the sample contracts are not mere arbitrary boilerplates that were randomly added to the contracts. More specifically, this study found a significant statistical association between the inclusion of an anti-course of performance clause in a contract and the inclusion of a variety of other related clauses, such as anti-waiver and anti-assignment clauses.

The theoretical and practical implications of these results are discussed.

\section{INTRODUCTION}

The course of performance doctrine-under which a contract can be modified by the post-contractual conduct of the parties ${ }^{1}$-is a basic building block of U.S. contract law. ${ }^{2}$ The desirability of the doctrine, however, has been a source of intense theoretical debate and controversy among legal scholars. ${ }^{3}$ The central theoretical argument that proponents of the doctrine present is that its application reflects the actual intention of the parties. ${ }^{4}$ Interestingly enough, the major theoretical argument presented by opponents of the doctrine is quite the opposite: the doctrine stands contrary to the intention of the parties. 5

While the theoretical debate over the course of performance doctrine is profound, extensive, and ongoing, there are no systematic empirical studies aimed at directly exposing the parties' true intention about the doctrine. Specifically, there are no studies concentrating on the frequency with which anti-course of performance clauses, which aim to prevent the application of the doctrine, are included by the parties in real-world contracts. The study contained in this Article aims to fill this research void.

Focusing on the preferences of sophisticated parties to commercial contracts, this Article analyzes 1,550 commercial contracts disclosed to the Securities and Exchange Commission (SEC). The results of the study reveal that the majority of contracts $(80.06 \%)$ include an anticourse of performance clause, known as a "no-oral-modification

1. See infra Part I.

2. Jennifer Camero, Mission Impracticable: The Impossibility of Commercial Impracticability, 13 U.N.H. L. REv. 1, 32-33 (2014) ("Usage of trade, course of dealing, and course of performance are mainstays of contract law ....").

3. See infra Part II.

4. See infra Part II.

5. See infra Part II. 
clause" (NOM clause). ${ }^{6}$ This clause stipulates that all modifications of the contract be made only in writing. The results also indicate that NOM clauses are not mere boilerplates that are inadvertently added to the contracts. Particularly, the study found a significant statistical association between the existence of a NOM clause and the existence of other related clauses-such as anti-waiver, anti-assignment, and notices clauses-which require the post-contractual actions of the parties to be made only in writing. ${ }^{7}$

This Article is structured as follows: Parts I and II will provide context by briefly reviewing the course of performance doctrine and the context underlining the theoretical debate over the desirability of the doctrine. Part III will present the empirical test of this study. It will review the data and discuss the methodology used for empirically testing the frequency with which a NOM clause is included in commercial contracts between sophisticated parties. It will also examine the statistical association between the NOM clause and related clauses. Part IV will discuss the normative implications of the empirical results.

\section{The Course of Performance Doctrine-An Overview}

A course of performance is legally defined as the sequence of conduct between the parties to the contract. ${ }^{8}$ It normally exists when two conditions are met: "(1) the agreement of the parties with respect to the transaction involves repeated occasions for performance by a party; and (2) the other party, with knowledge of the nature of the performance and opportunity for objection to it, accepts the performance or acquiesces in it without objection." 9

According to the general rules of contract law, the course of performance doctrine has one major implication, which is the focus of this paper: a written contract may be modified by course of performance. ${ }^{10}$ As Professor Hillman illustrates, if a gardener and her client

6. See infra Part III.A.

7. See infra Part III.E.

8. U.C.C. § 1-303(а) (Ам. Law Inst. \& Unif. Law Comm’n 2013); Fire Supply \& Serv., Inc. v. Chico Hot Springs, 639 P.2d 1160, 1164 (Mont. 1982); J.W.S. Delavau, Inc. v. Eastern Am. Transport and Warehousing, Inc., 810 A.2d 672, 683-84 (Pa. Super. Ct. 2002); 2 E. Allan Farnsworth, Farnsworth on Contracts 329 (3rd ed. 2004); Joseph M. Perillo, Contracts 150 (7th ed. 2014).

9. U.C.C. $\$ 1-303(a)$. The common law adopted similar conditions as the ones used in the U.C.C. See Farnsworth, supra note 8, at 330; Eric A. Posner, Contract Law and Theory 140 (2011); see also Restatement (Second) of Contracts § 202(4) (Am. Law. Inst. 1981).

10. U.C.C. $\S 1-303(\mathrm{f})$ ("[A] course of performance is relevant to show a . . modification of any term inconsistent with the course of performance."); Kaplan v. Old Mut. PLC, 526 F. App'x 70, 72 (2d Cir. 2013) (quoting Dallas Aerospace, Inc., v. CIS Air Corp., 352 F.3d 775, 783 (2d Cir. 
agree that the gardener will mow the client's lawn every Saturday during the summer, but during the month of July the gardener actually mowed the lawn every Sunday without the client objecting, then course of performance may have modified the contract, thus requiring Sunday mowing. ${ }^{11}$

A modification of a contract by course of performance normally incorporates several noteworthy implications: First, the modification may terminate certain rights afforded under the original agreement (e.g., the client's right to have the lawn mowed on Saturday). ${ }^{12}$ Second, the modification can add new duties, by either expanding existing duties or imposing new duties on the parties (e.g., the client's new duty to accept Sunday mowing). ${ }^{13}$ Third, the new modified contract is

2003)) ("Under New York law, "parties may modify a contract "by . . course of performance ....",”); Lauderdale Cty. Sch. Dist. ex rel. Bd. of Educ. v. Enter. Consol. Sch. Dist., 24 F.3d 671, 687 (5th Cir. 1994) ("Under Mississippi state law, the subsequent actions of the parties may modify the contract . . . ."); Davidson v. Yihai Cao, 211 F. Supp. 2d 264, 282 (D. Mass. 2002) ("Under Illinois law, '[a] contract is validly modified if the party which did not propose the changes is shown to acquiesce in the modification through a course of conduct." ); Safeguard Bus. Sys., Inc. v. Hoeffel, No. 89-2444-O, 1991 U.S. Dist. LEXIS 1334, at*13 n.3 (D. Kan. 1991) ("Kansas follows the general rule of contract law that terms of a written contract may be modified by the parties' mutual course of conduct."); Motown Record Corp. v. Mary Jane Girls, Inc., 650 F. Supp. 123, 125 (S.D.N.Y. 1986) ("California law permits the modification of a contract by conduct.”); Trident Elec., Inc. v. John S. Clark, Inc., CH05-532, 2008 Va. Cir. LEXIS 5, at *12 (Va. Cir. Ct. Feb. 8, 2008) ("Under North Carolina law, while the provisions of a written contract are generally enforced, they can absolutely be . . modified by the conduct and actions of the parties.”); Omri Ben-Shahar, The Tentative Case Against Flexibility in Commercial Law, 66 U. CHI. L. Rev. 781, 790 (1999) ("[I]n a long line of cases courts have held that course of performance can trump conflicting terms in the contract."); JOHN EDWARD MurRAY, JR., MurRAy ON CONTRACTs 478-79 (5th ed. 2011) ("[C]ourse of performance . . . may constitute a modification of the contract."); Perillo, supra note 8, at 153 ("A course of performance may add a term to the agreement or subtract one."). Notably, the course of performance doctrine has another less dramatic implication than contract modification: a course of conduct may be relevant in ascertaining the meaning of an expression in the parties' agreement. See U.C.C. § 1-303(d); Restatement (Second) of Contracts $§ 202(4)$; Robert A. Hillman, Principles of Contract Law 254 (2d ed. 2009) ("[C]ourse of performance evidence may help determine what a reasonable person would believe an ambiguous [term] means."); Murray, supra note 10, at 478 ("[C]ourse of performance evidence is admissible to interpret the expressions of the parties."); PERILLO, supra note 8, at 153 ("A course of performance may also be relevant on the issue of meaning.").

11. Hillman, supra note 10, at 254; Similarly, if a buyer is contractually entitled to receive seven shipments of goods at a specific location, but has accepted three times, and without objection, delivery at a different location, then course of performance may modify the contract. Daphna Lewinsohn-Zamir, More is Not Always Better than Less-An Exploration in Property Law, 92 Minn. L. Rev. 634, 710-11 (2008).

12. Int'l Bus. Lists v. AT\&T, 147 F.3d 636, 641 (7th Cir. 1998) ("A modification of a contract is a change in one or more respects which introduces new elements into the details of the contract and cancels others."); PERILlo, supra note 8, at 153 ("A course of performance may . . . subtract" a term from the agreement).

13. Murray, supra note 10, at 479 (“[C]ourse of performance may provide new terms ...."); Perillo, supra note 8, at 153 ("A course of performance may add a term to the agreement ...."). 
legally binding, as was the original contract. ${ }^{14}$ Fourth, the modification of the agreement cannot be withdrawn unilaterally by one of the parties, rather only by mutual agreement between the parties (e.g., the gardener and her client). ${ }^{15}$

A course of performance, which may constitute contract modification, should be distinguished from two related principles of contract law: course of dealing and trade of usage. While course of performance occurs after the contract was made ${ }^{16}$ course of dealing concerns the conduct of the parties prior to contract formation. ${ }^{17}$ In addition, while course of performance focuses on the particular relationship between the parties, usage of trade is a general practice that can be regularly observed in a particular commercial industry. ${ }^{18}$

14. Meijer v. Thompson, 655 F. Supp. 2d 607, 614 (E.D. Va. 2009) (“[A] modification is . . binding"); Martin H. Brinkley, The Regulation of Contractual Change: A Guide to No Oral Modification Clauses for North Carolina Lawyers, 81 N.C. L. REv. 2239, 2253 (2003) ("Modifications are themselves contracts, . . . having the full permanent and binding effect of an original agreement.").

15. Nassau Trust Co. v. Montrose Concrete Prods. Corp., 436 N.E.2d 1265, 1269 (N.Y. 1982) (“A modification . . . may only be withdrawn by agreement."); see also Williams v. Chapman, 22 A.D.3d 1015, 1017 (N.Y. App. Div. 2005).

16. FARNSWORTH, supra note 8, at 329 (A course of performance "consists of conduct subsequent to the agreement . . .."); Perillo, supra note 8, at 150 ("[A] course of performance involves conduct after the agreement has been made . ...") (emphasis omitted).

17. U.C.C. $\S 1-303(b)$ ("A 'course of dealing' is a sequence of conduct concerning previous transactions between the parties ....”); Restatement (SECOND) OF Contracts § 223(1) (AM. LAw. INST. 1981) ("A course of dealing is a sequence of previous conduct between the parties . . . "); FARnSwORTH, supra note 8, at 329 (stating that course of performance "should not be confused with a 'course of dealing,' which consists of conduct prior to the agreement in question."); Hillman, supra note 10, at 254 ("The main difference between a course of dealing and course of performance lies in when the conduct takes place. If the conduct occurred as part of a particular contract it is called a course of performance. If the conduct occurred prior to the contract at issue it is called a course of dealing."); Perillo, supra note 8, at 150 ("A course of dealing relates to the conduct prior to the agreement.") (emphasis omitted); see also JAMES White \& Robert S. Summers, Uniform Commercial Code 140 (6th ed. 2010).

18. U.C.C. $\$ 1-303$ (c) ("A 'usage of trade' is any practice or method of dealing having such regularity of observance in a place, vocation, or trade as to justify an expectation that it will be observed with respect to the transaction in question."); RESTATEMENT (SECOND) OF CONTRACTS $\S 222$ ("A usage of trade is a usage having such regularity of observance in a place, vocation, or trade as to justify an expectation that it will be observed with respect to a particular agreement."); cf. White \& Summers, supra note 17, at 589-91; William H. Widen, The Arbitrage of Truth: Combating Dissembling Disclosure, Derivatives, and the Ethic of Technical Compliance, 66 U. MiAmi L. REv. 393, 414 (2012) ("[T]he usage reflected in the course of performance of the particular contract takes priority over prior use between the parties in previous contracts or the language use prevalent in the trade in general.") (emphasis added). In addition, while a course of performance can be normally proved by the testimony of the parties, trade usage is usually proved by expert testimony. See Perillo, supra note 8, at 151 . 


\section{The Theoretical Debate over Course of Performance}

Proponents of the course of performance doctrine base their support for the doctrine mainly on an intention-of-the-parties rationale. They particularly argue, on a theoretical level, that the parties' course of performance during the contractual relationship is the strongest indication of the parties' true intentions as to the scope of their mutual obligations. ${ }^{19}$ This argument rests on an assumption that the parties' intentions are dynamic rather than static. ${ }^{20}$ When making the written contract, the parties intended to be governed by said formal contract. ${ }^{21}$ However, as their contractual relationship evolves, the parties' mutual subjective intention evolves to modify their obligations to meet changing circumstances. ${ }^{22}$ This new intention is inferred from the parties' repeated course of conduct. ${ }^{23}$ In such case, the course of performance doctrine appropriately prefers the parties' new, ex post intention, reflected in their repeated conduct, over their ex ante intention, reflected in their one-time written contract. ${ }^{24}$

19. John M. Breen, Statutory Interpretation and the Lessons of Llewellyn, 33 Loy. L.A. L. REv. 263, 341 (2000) (The course of performance doctrine suggests "that the parties' intent may be found in their actual conduct."); Lewinsohn-Zamir, supra note 11, at 711 ("The common explanation for the [course of performance] doctrine is that the parties' conduct during performance is the best indicator of their actual intentions and of the modifications they have agreed to."); John E. Murray, Jr., The Chaos of the "Battle of the Forms": Solutions, 39 VAnd. L. REv. 1307, 1314 (1986) (The parties' course of performance "not only will provide the strongest evidence of their contract's intended meaning; it also will operate to overcome their previously expressed terms.”); John E. Murray, Jr., The Emerging Article 2: The Latest Iteration, 35 DuQ. L. REv. 533, 566 (1997) ("Course of performance provides the strongest evidence of what the parties intended by the original terms and can also operate as a modification of such terms ...."); Perillo, supra note 8, at 153 ("A course of performance is often the best evidence of the parties' intentions."); Frank A. Rothermel, Comment, Role of Course of Performance and Confirmatory Memoranda in Determining the Scope, Operation and Effect of "No Oral Modification" Clauses, 48 U. PitT. L. REv. 1239, 1252-53 (1987) (“[T]he parties' course of performance in executing their contract was perhaps the most important and reliable evidence of the parties' true intent concerning their contractual obligations."); David V. Snyder, Language and Formalities in Commercial Contracts: A Defense of Custom and Conduct, 54 SMU L. REv. 617, 643 (2001) ("Course of performance is good evidence of what the terms of the contract are considered to be by the parties, and that is precisely the goal of assent-based construction.").

20. Ben-Shahar, supra note 10 , at 788 .

21. Ben-Shahar, supra note 10 , at 788 .

22. Ben-Shahar, supra note 10 , at 788 .

23. Ben-Shahar, supra note 10, at 788; see also Murray, supra note 10, at 479 ("If the parties have knowingly engaged in repeated occasions of performance which are inconsistent with the express terms of the contract, they have manifested their intention to modify their contract.").

24. Ben-Shahar, supra note 10 , at 788 ("[B]y integrating the parties' past practices into the relationship, the law favors the parties' ex post intention over their ex ante, 'historical' intention . . . "); Robert A. Hillman, Comment: More in Defense of U.C.C. Methodology, 62 LA. L. REv. 1153, 1157 n.40 (2002) ("[A] court ... may strike a term barring evidence of a subsequent course of performance on the theory that the parties ex post conduct shows their intention to disregard the written term."); John E. Murray, Jr., Contract Theories and the Rise of Neoformalism, 71 
According to proponents of the doctrine, the course of performance doctrine is the best indication of the parties' intention. This is supported by three major benefits that the doctrine hypothetically provides to the parties.

First, the course of performance doctrine facilitates the flexibility of the parties during the contractual relationship. ${ }^{25}$ More specifically, this argument is based on an assumption that contractual relationships often informally adjust to changing circumstances. ${ }^{26}$ For example, if a buyer is suddenly short of warehouse space during a contractual delivery period, the seller may delay the delivery in accordance with the buyer's interest and in contrast with the written contract. ${ }^{27}$ Given the existence of dynamic, informal adjustments during the contract, there is often a disparity between these adjustments and the written contract. ${ }^{28}$ When such disparities exist, the course of performance doctrine "facilitates flexible and informal adjustments of contractual

Fordham. L. Rev. 869, 893 (2002) [hereinafter Contract Theories and the Rise of Neoformalism] ("Where a course of performance differs from the express terms, it constitutes a modification ... of the express terms because it is a clear and current manifestation that the parties have changed their minds."); Corneill A. Stephens, On Ending the Battle of the Forms: Problems with Solutions, 80 KY. L.J. 815, 838 (1992) ("By expressly including . . . course of performance . . . when the contract results from conduct, an attempt to reach the intention of the parties is assured.").

25. Lewinsohn-Zamir, supra note 11, at 711 (stating that the course of performance doctrine "facilitates flexible and informal adjustments of contractual obligations."); see also BenShahar, supra note 10, at 784 n.19 ("Most commentators seem to believe that doctrines like . . course of performance increase the flexibility of the relationships."); Lisa Bernstein, Merchant Law in a Modern Economy, in Philosophical Foundations of Contract Law 238, 257 (Gregory Klass et al. eds., 2014) [hereinafter Merchant Law in a Modern Economy] (stating that the course of performance doctrine was "designed to encourage work-a-day contractual flexibility ....").

26. Anadarko Petroleum Corp. v. Williams Alaska Petroleum, Inc., 737 F.3d 966, 971 (5th Cir. 2013) ("[T]he undisputed evidence shows that the parties' course of performance indicates that they consistently made adjustments to the amount of payment due at a time after the contract payment date ...."); Larry A. DiMatteo, Equity's Modification of Contract: An Analysis of the Twentieth Century's Equitable Reformation of Contract Law, 33 NEw ENG. L. REv. 265, 312 (1998) ("Adjustments during the course of performance have become so routine in certain industries ...."); Daniel Markovits, Contract and Collaboration, 113 YALE L.J. 1417, 1455 (2004) ("[A]s any contract lawyer knows, the administration even of the very simplest joint plan requires constant addition, revision, and adjustment over the course of its performance."); Eyal Zamir, The Inverted Hierarchy of Contract Interpretation and Supplementation, 97 Colum. L. REV. 1710, 1765 (1997) (arguing that the gap between the parties' set of legal rights and obligations and their course of performance "is reflected in the adaptation of the contract to changing circumstances and to changes in the parties' wishes ....").

27. Lisa Bernstein, Private Commercial Law in the Cotton Industry: Creating Cooperation Through Rules, Norms, and Institutions, 99 Mich. L. REv. 1724, 1744 (2001) [hereinafter Private Commercial Law in the Cotton Industry].

28. Zamir, supra note 26, at 1765 ("Empirical research indicates that there is a wide gap between the parties' set of 'legal' rights and obligations and their actual behavior during the performance of the contract."). 
obligations." 29 It particularly does so by informally modifying the contract according to the parties' course of performance, thereby eliminating the transaction costs needed to formally rewrite the contract in accordance with such performance..$^{30}$

Second, the course of performance doctrine protects the reasonable reliance of a relying party. More concretely, when one contractual party repeatedly allows a practice to go without objection, she may create an expectation on the part of the other party that this practice has become part of the contractual relationship. ${ }^{31}$ In order to protect the reliance interest of the relying party, the doctrine allows that party's course of conduct to modify the written contract. ${ }^{32}$

Third, the doctrine allows the parties to correct incompleteness errors that they have made during the formation of the contract. ${ }^{33}$ These errors typically occur when the parties, while drafting the contract, unintentionally overlook a low-probability scenario which may have significant ramifications for the parties. ${ }^{34}$ However, during the contractual relationship, the parties' repeated experience with a lowprobability scenario may generate a course of performance between the parties regarding this scenario. ${ }^{35}$ In such a case, the course of performance doctrine, by modifying the contract, provides the parties

29. Lewinsohn-Zamir, supra note 11 , at 711 ; see also Ben-Shahar, supra note 10, at 784 n.19 ("Most commentators seem to believe that doctrines like ... course of performance increase the flexibility of the relationships."); Allen R. Kamp, Between-the-Wars Social Thought: Karl Llewellyn, Legal Realism, and the Uniform Commercial Code in Context, 59 Alb. L. Rev. 325, 336 (1995) (" 'Course of performance' was to be given legal effect to allow for binding adjustments to be made ....").

30. Ben-Shahar, supra note 10, at 788 (The course of performance doctrine "saves the parties the transaction cost of formally redrafting the bargain."); Lewinsohn-Zamir, supra note 11, at 711 (stating that the course of performance doctrine creates "saving on the transaction costs to the parties of negotiating contract modifications.").

31. Ben-Shahar, supra note 10, at 789 ("[W]hen a party allows a conflicting practice to go unchallenged even though she has the right to enforce the explicit provisions of the contract, she creates an expectation on the part of the other party that she will not enforce the explicit provisions prospectively.") (emphasis omitted).

32. Ben-Shahar, supra note 10, at 789 ("In order to protect the reliance interest of a party who incurs opportunity costs while reasonably expecting an ongoing practice to persist, the law allows the ongoing practice to override the explicit provisions.").

33. Charles J. Goetz \& Robert E. Scott, The Limits of Expanded Choice: An Analysis of the Interactions Between Express and Implied Contract Terms, 73 CALIF. L. REv. 261, 279 (1985) ("[A] course of . . performance also reduces what we have described as incompleteness error.").

34. Id. at 270 ("This 'incompleteness error' typically occurs when the parties inadvertently overlook a potentially important, but low probability contingency."); see also Michal Shur-Ofry \& Ofer M. Tur-Sinai, Constructive Ambiguity: IP Licenses as a Case Study, 48 U. Mich. J.L. REFORM 391, 399 (2015) ("[A] contract may simply avoid addressing a certain scenario or its consequences, despite their potential relevance to the transaction.").

35. Goetz \& Scott, supra note 33, at 279 ("But repeated experience with low-probability events tends to reveal patterns of behavior between the parties."). 
with specific terms for handling low-probability scenarios, thereby fixing incompleteness errors. ${ }^{36}$

Opponents of the course of performance doctrine argue, on a theoretical level, that the application of the doctrine stands contrary to the parties' intentions. ${ }^{37}$ This argument rests on an assumption that the parties have two different types of intentions. The first type relates to the question of how typical, non-litigated issues should be handled by the parties during their contractual relationship. ${ }^{38}$ Consider, for example, a contract for the sale of feed between a buyer and a seller. The agreement may include an official weight provision demanding the seller to provide the buyer with a federally-supervised weight certificate. ${ }^{39}$ However, small buyers and sellers of feed may often intend that throughout their contractual relationship they will accept the seller's unsupervised in-house weights, given the high cost of official weights. ${ }^{40}$ The second type of intention relates to the question of how atypical, litigated cases should be formally treated by courts. ${ }^{41}$ For example, the small feed merchandisers may often desire that the official weight provisions in their contracts will be strictly applied by courts in a litigated dispute. ${ }^{42}$

36. Goetz \& Scott, supra note 33, at 279 ("By increasing the supply of party-specific terms, the state thus promotes reductions in incompleteness risks."). Relatedly, it is theoretically argued that the course of performance doctrine can fix "administrative errors" (e.g. typos) by modifying the written contract in accordance with the parties' course of performance, which reflects their accurate intention. $I d$. at 268, 279.

37. Alan Schwartz \& Robert E. Scott, Contract Theory and the Limits of Contract Law, 113 YALE L.J. 541, 592 (2003) (“[T]he courts' use of course of performance evidence to establish a change in meaning reflects a misunderstanding of the parties' likely intentions.").

38. Id. at 593-94 ("The parties' amicable behavior after the contract likely evidences only their view regarding how the average case should be treated . . . Their actions under the contract will evidence their intentions for typical cases . . ..").

39. Lisa Bernstein, Merchant Law in a Merchant Court: Rethinking the Code's Search for Immanent Business Norms, 144 U. PA. L. REv. 1765, 1764-65 n.96 (1996) [hereinafter Merchant Law in a Merchant Court].

40. $I d$. at 1799 ("[W]hile smaller feed merchandisers who transact primarily on a local or regional basis often include official weight provisions in their contracts, they routinely accept one another's unsupervised in-house weights.").

41. Id. at 1796 ("[T] he terms of transactors' written contracts, . . . contain the norms that transactors would want a third-party neutral to apply in a situation where they were unable to cooperatively resolve a dispute and viewed their relationship as being at an end-game stage."); Schwartz \& Scott, supra note 37, at 593-94 ("When business parties incur costs to cast obligations in written form, they do so partly to permit a party to stand on its rights under the written contract when standing on its rights matters .... Courts ... see the unusual case that the contract was written to govern.").

42. Merchant Law in a Merchant Court, supra note 39, at 1799 (stating that contracts of small feed merchandisers often include an "explicit contractual provision embodying the desired [endgame norm applied by courts]—a provision requiring official weights.”). 
Given these two different types of intentions by the parties, opponents of the course of performance doctrine believe that the parties' course of conduct during the contractual relationship evidences only their first type of intention, namely how non-litigated issues should be handled by the parties themselves during their relationship. ${ }^{43}$ In contrast, the content of the formal written contract evidences the parties' second type of intention, namely how a litigated case should be formally handled by courts. ${ }^{44}$ Accordingly, a court is likely to make an error when it relies on the parties' course of performance to conclude how the parties intended their disputed case to be resolved by a court. ${ }^{45}$

According to opponents of the doctrine, the theoretical argument that the course of performance doctrine stands in contrast with the intention of the parties is supported by three major supposed disadvantages.

First, the doctrine discourages contractual flexibility by the parties during their relationship, ${ }^{46}$ as opposed to the prediction made by proponents of the doctrine. ${ }^{47}$ More specifically, proponents predict that a contract party would often wish to behave flexibly towards the other party during the life of the contract in order to preserve their contractual relationship. ${ }^{48}$ However, if a party to a contract anticipates that courts will use its flexibility, as reflected in its course of performance, to impose legal duties on it in future disputes between the parties, it

43. Schwartz \& Scott, supra note 37, at 593-94 ("The parties' amicable behavior after the contract likely evidences only their view regarding how the average case should be treated . . . Their actions under the contract will evidence their intentions for typical cases.").

44. Schwartz \& Scott, supra note 37, at 593-94 ("When business parties incur costs to cast obligations in written form, they do so partly to permit a party to stand on its rights under the written contract when standing on its rights matters ... . Courts ... see the unusual case that the contract was written to govern.").

45. Schwartz \& Scott, supra note 37, at 594 ("[A] court is likely to make a category mistake when it relies on parties' behavior in nonlitigated cases to infer how parties want a litigated case to be treated.").

46. Merchant Law in a Merchant Court, supra note 39, at 1808 (stating that under the course of performance doctrine, the parties are "less likely to flexibly adjust their contractual obligations."); Merchant Law in a Modern Economy, supra note 25, at 257 (arguing that the course of performance doctrine was "designed to encourage work-a-day contractual flexibility; yet [it is] likely to have precisely the opposite effect."); Jack W. Graves, Course of Performance as Evidence of Intent or Waiver: A Meaningful Preference for the Latter and Implications for Newly Broadened Use Under Revised UCC Section 1-303, 52 Drake L. REv. 235, 277 (2004) ("If we really want to encourage the greatest degree of flexible cooperation between the parties to an agreement, the best approach would be to bar all evidence of their postformation conduct in deciding their respective rights and duties.").

47. See supra notes 25-30 and accompanying text.

48. Merchant Law in a Modern Economy, supra note 25, at 257 ("In the course of business operations, there are adjustments that transactors find it worthwhile to make at a particular point in time . . . ."); see also Merchant Law in a Merchant Court, supra note 39, at 1796. 
will be less likely to behave flexibly toward the other party in the first place. ${ }^{49}$ The course of performance doctrine might therefore inefficiently deter contractual parties from being flexible, ${ }^{50}$ creating what some legal scholars label as a "rigidity effect." 51 As Professor Hillman illustrates, under the doctrine, when a lawn owner lets her gardener mow her lawn on a few successive Sundays, although the written contract calls for mowing on Saturdays, the owner may lose the contractual right to insist that the gardener mow the lawn on Saturdays. ${ }^{52}$ As a result, the owner might "rigidly insist" that the gardener mow her lawn only on Saturdays, in order to avoid losing her contractual right..$^{53}$ Such rigidity might arguably be inefficient, since sometimes Sunday mowing may generate economic benefit to the gardener while imposing no cost on the owner. ${ }^{54}$

Second, the doctrine may make it "more difficult [for the parties] to create stable frameworks for renegotiation . . . ." 55 Contract parties, who anticipate that they will have to renegotiate particular aspects of their contract, may intentionally draft written contractual clauses that

49. Merchant Law in a Modern Economy, supra note 25, at 257; see also Merchant Law in a Merchant Court, supra note 39, at 1808; Matthew C. Jennejohn, Contract Adjudication in a Collaborative Economy, 5 VA. L. \& Bus. REv. 175, 179 (2010).

50. Ben-Shahar, supra note 10, at 784 ("[P]ractices of mutual flexibility and leniency might be deterred if courts treat these practices as amendments to, or variations of, the parties' explicit contract."); David V. Snyder, The Law of Contract and the Concept of Change: Public and Private Attempts to Regulate Modification, Waiver, and Estoppel, 1999 Wis. L. REv. 607, 637 (1999) ("[T] $]$ oo exalted a role for course of performance results in disincentives to utility-enhancing adjustments in the ongoing relationship.").

51. Ben-Shahar, supra note 10, at 784; Jennejohn, supra note 49, at 203-04; Juliet P. Kostritsky, Judicial Incorporation of Trade Usages: A Functional Solution to the Opportunism Problem, 39 Conn. L. Rev. 451, 511-12 (2006); Juliet P. Kostritsky, Plain Meaning vs. Broad Interpretation: How the Risk of Opportunism Defeats a Unitary Default Rule for Interpretation, 96 Ky. L.J. 43, 92 (2008); Contract Theories and the Rise of Neoformalism, supra note 24, at 896.

52. Hillman, supra note 10, at 255.

53. Hillman, supra note 10, at 255. But see Professor Hillman's criticism on this argument. Hillman, supra note 10, at 255.

54. Private Commercial Law in the Cotton Industry, supra note 27, at 1743 ("There are often stages in a contracting relationship at which adjustments that create tremendous benefits to one party while imposing minimal costs on the other can, in fact, be made; yet transactors would be far less willing to make these adjustments if there was even a small risk that they might be required to do so in the future, a risk that is very real in the public legal system due to the Code's ... course of performance provisions."). Moreover, it is theoretically argued that the course of performance doctrine may encourage post-contractual opportunism. A party who failed to get a specific right in the contract might insist that although the contract does include the right, it was added to the contract by course of performance. See Jason Scott Johnston, Should the Law Ignore Commercial Norms? A Comment on the Bernstein Conjecture and its Relevance for Contract Law Theory and Reform, 99 MicH. L. REv. 1791, 1803 (2001).

55. Merchant Law in a Merchant Court, supra note 39, at 1807-08. 
will set a stable benchmark for future renegotiation. ${ }^{56}$ However, if contract parties predict that courts will apply their course of performance to modify the written contract, they may find it difficult to draft a "stable framework for renegotiation." 57 As repeated and informal adjustments to the contract are often made by the parties, the doctrine may imply that the written contract will be constantly modified, making the written contractual framework unstable. 58

Third, the application of the doctrine by courts suffers from several limitations which may eventually harm the parties. First, the parties' sequence of conduct, alleged by one of the parties in court, may be derived from a relatively small amount of factual events. ${ }^{59}$ As a result, courts would have difficulty distinguishing true patterns of behavior from false ones. ${ }^{60}$ Relatedly, the court's analysis of the factual evidence relating to an alleged course of performance might be inaccurate, ${ }^{61}$ given that judicial resources are limited. ${ }^{62}$ In addition, courts have difficulty determining what degree of repetition of the behavioral interactions between the parties is necessary. ${ }^{63}$ While a common definition of course of performance requires "repeated occasions" for performance by either party, ${ }^{64}$ it is often unclear how many occasions

56. Merchant Law in a Merchant Court, supra note 39, at 1811.

57. Merchant Law in a Merchant Court, supra note 39, at 1811 ("[I]f transactors anticipate that courts will permit course of performance to alter the meaning of their written contract, it may be difficult for them to draft provisions that will set a desirable and stable framework for renegotiation.").

58. Merchant Law in a Merchant Court, supra note 39, at 1811-12 ("As their contracting relationship develops and repeated adjustments are made, the fact that in the event that renegotiation fails, courts will look to course of performance in . . . deciding whether a . . modification of [the contract] terms has been made means that each transactor's threat point in the renegotiation, the point which defines the position that she will be in if renegotiation is unsuccessful, will constantly change, making nearly any framework for renegotiation established at the time of contracting inherently unstable.").

59. Goetz \& Scott, supra note 33, at 276 ("[T] he alleged patterns in the behavior of particular parties may be derived from a quite limited number of occurrences."); Jennejohn, supra note 49, at 207 (The problem with relying on parties' course of performance is that "courts have insufficient information from which to glean patterns in the disputants' behavior.").

60. Goetz \& Scott, supra note 33, at 276 ("The number of observations may be so small that an observer would have difficulty distinguishing valid inferences from spurious ones.").

61. Jennejohn, supra note 49, at 207; Johnston, supra note 54, at 1803 ("Even if the parties intended for such concessions to in fact modify their future obligations, there is much too high a probability that courts will err in determining what the parties have actually done or said in their prior dealings.").

62. Jennejohn, supra note 49, at 207.

63. Hillman, supra note 10, at 255 ("Courts have had little trouble determining when the parties have established a course of performance . . ."); Goetz \& Scott, supra note 33, at 276 ("Courts experience grave difficulty determining the degree of repetition necessary to establish a 'course' of conduct.").

64. U.C.C. § 1-303(а) (Ам. LAw InST. \& Unif. LAw Comm’n 2013); Stewart v. Screen GemsEmi Music, Inc., 81 F. Supp. 3d 938, 964 (N.D. Cal. 2015); Stalloy Metals, Inc. v. Kennametal, 
are needed in order to constitute the repetition necessary to establish a course of performance. ${ }^{65}$

Given the profound theoretical debate over whether the course of performance doctrine reflects the intentions of the parties, an important question that arises is what the actual intention of the parties is. The purpose of the next Part of this article is to address this question empirically.

\section{The Empirical Test}

There is a rich theoretical debate over the whether the course of performance doctrine reflects the intentions of the parties. ${ }^{66}$ However, the existing debate lacks a quantitative, empirical analysis concentrating on the parties' intentions. Focusing on the intentions of sophisticated parties to commercial contracts, this chapter tests the frequency with which anti-course of performance clauses, known as no-oralmodification (NOM) clauses, are included in real-world commercial contracts.

\section{A. No-Oral-Modification Clause-A Brief Overview}

A NOM clause is a contractual provision requiring modifications of the written contract to be made only in writing. ${ }^{67} \mathrm{~A}$ typical NOM clause states, inter alia: "The contract may be modified . . . only in a writing . ..." ${ }_{68}$ As implied by the text of a typical NOM clause, the clause bars the modification of the contract not only orally but also by course of performance. ${ }^{69}$ This is mainly because course of perform-

Inc., 983 N.E.2d 823, 835 (Ohio Ct. App. 2012); Restatement (SECOnd) of Contracts $\S 202(4)$ (Aм. Law. Inst. 1981).

65. Goetz \& Scott, supra note 33, at 276 n.41 (stating that the U.C.C. does not supply "guidance on how many acts are needed" in order to establish a course of performance).

66. See supra Part II.

67. E. Allan Farnsworth, The Interpretation of International Contracts and the Use of Preambles, 2002 InT'L Bus. L.J. 271, 274 [hereinafter The Interpretation of International Contracts and the Use of Preambles] (stating that a NOM clause recites that "no modification of the contract is valid unless in writing."); Heather Piotrowski, Legalizing Fraud in Michigan Contract Law, 58 WAYNE L. REv. 139, 152 n.97 (2012) (explaining that a NOM clause requires that "any modifications to the written document must be in writing."); Ma del Pilar Perales Viscasillas, Modification and Termination of the Contract (Art. 29 CISG), 25 J.L. \& CoM. 167, 170 (2005) (stating that NOM clauses "do not allow for the modification of the contract unless that modification is made in writing.").

68. FARNSwORTH, supra note 8 , at 258.

69. Schwartz \& Scott, supra note 37, at 592 (arguing that courts should be reluctant to admit course-of-performance evidence to show a change in the meaning of the contract "when the contract contains a term requiring modifications to be in writing."); The Interpretation of International Contracts and the Use of Preambles, supra note 67, at 277. The contract drafter can use, inter alia, a no-oral-modification clause in an attempt to prevent post-contractual conduct from 
ance is a sequence of conduct, ${ }^{70}$ which by its very nature does not constitute a "writing." In essence, a NOM clause is, among other things, an anti-course of performance clause.

Importantly, the inclusion of a NOM clause in a contract reflects an effort by the parties to prevent the application of the course of performance doctrine. However, the enforceability of NOM clauses under U.S. law is unclear. ${ }^{71}$ While some courts are reluctant to enforce NOM clauses, ${ }^{72}$ other courts tend to uphold such clauses. ${ }^{73}$ The latter courts particularly bar the modification of the contract through course of performance, where the contract includes a NOM clause. ${ }^{74}$ Given

modifying the contract. The Interpretation of International Contracts and the Use of Preambles, supra note 67, at 277.

70. See supra text accompanying note 8 .

71. Martin H. Brinkley, The Regulation of Contractual Change: A Guide to No Oral Modification Clauses for North Carolina Lawyers, 81 N.C. L. REv. 2239, at 2245-46 (2003) ("North Carolina law on the enforceability of NOM . . clauses, like the law of some other states and federal jurisdictions, is undeveloped and confused."); The Interpretation of International Contracts and the Use of Preambles, supra note 67, at 274 (explaining that the law on the effect of NOM clauses "is uncertain."); Robert A. Hillman, Article 29(2) of the United Nations Convention on Contracts for the International Sale of Goods: A New Effort at Clarifying the Legal Effect of No Oral Modification Clauses, 21 CoRnell INT'L L.J. 449,449 (1988) [hereinafter Article 29(2) of the United Nations Convention on Contracts for the International Sale of Goods] ("The legal effect of NOM clauses in this country is shrouded in mystery.").

72. See, e.g., Gaia House Mezz LLC v. State St. Bank \& Tr. Co., 720 F.3d 84, 90 (2d Cir. 2013) (quoting Harold J. Rosen Tr. v. Rosen, 386 N.Y.S.2d 491, 499 (N.Y. App. Div. 1976)) (“[A]ny written agreement, even one which provides that it cannot be modified except by a writing signed by the parties, can be effectively modified by a course of actual performance."); In re Winstar Commc'ns, Inc., 554 F.3d 382, 410 (3d Cir. 2009) ("New York law provides that any contract may be modified by a course of performance, even if that contract otherwise requires modifications to be in writing."); Prusky v. Phoenix Life Ins. Co., No. 02-6010, 2005 U.S. Dist. LEXIS 32856, at *53 (E.D. Pa. July 26, 2005) ("Pennsylvania courts, nevertheless, have allowed modification of a written agreement, even with a no-oral modifications clause, by subsequent parol negotiation or action of the parties.”); Fraher Transit, Inc. v. Aldi, Inc., 2009-Ohio-336, II 13, 2009 Ohio App. LEXIS 281, 2009 WL 187937 (Ohio Ct. App. 2009) ("[T]he no-oral-modification clause has not garnered favor in the law.").

73. See, e.g., Oki Distrib. v. Amana Refrigeration, Inc., 850 F. Supp. 637, 641 (S.D. Ohio 1994) ("[U]nder Iowa law, where a signed contract contains a clause excluding modification or recision [sic] except by a signed writing, the contract cannot be otherwise modified or rescinded."); Benz Farm, LLP v. Cavendish Farms, Inc., 2011 ND 184, II 12, 803 N.W.2d 818, 823 (N.D. 2011) ("Nooral modification clauses are enforced under North Dakota law."); Healy v. Williams, 818 N.Y.S. 121, 123 (N.Y. App. Div. 2006) ("As a general rule, where a contract has a provision which explicitly prohibits oral modification, such clause is afforded great deference ...."); Leasing Serv. Corp. v. Benson, 464 A.2d 402, 407 (Pa. Super. Ct. 1983) ("Our law generally upholds the validity and sanctity of no-oral modification clauses.").

74. See, e.g., Oki Distrib., 850 F. Supp. at 641 ("[W]here, as here, a contractual clause prohibits any modification which is not embodied in a signed writing, the parties are barred under Iowa law from modifying the contract . . through . . . course of conduct.”); Yackobovitz v. Se. Pa. Transp. Auth., 590 A.2d 40, 48 (Pa. Commw. Ct. 1991) ("Because of the "no modification unless in writing' clause, the City's conduct of assuming roadbed maintenance could not operate to permanently change the contract . . .."); see also U.C.C. § 2-209(2) (“A signed agreement which 
the chances that a NOM clause will be enforced by some courts, parties willing to avoid the application of the course of performance doctrine are likely to include the clause in their contract. ${ }^{75}$ Accordingly, the frequency with which NOM clauses are included by the parties in real-world contracts can indicate the intention of the parties regarding the course of performance doctrine.

\section{B. The Theoretical Hypotheses}

This Article hypothesizes that sophisticated parties are likely to include a NOM clause in their commercial contracts. A NOM clauseby requiring contract modifications to be made only in writing - has several significant organizational benefits for sophisticated parties, which were mostly overlooked in the theoretical debate over the desirability of the course of performance doctrine. ${ }^{76}$ To begin with, documenting contract modifications in writing can assist sophisticated parties in systematic ex ante evaluation of the potential economic implications of the proposed written changes. ${ }^{77}$ Such an evaluation might be particularly important for sophisticated parties since contract modifications may have significant financial ramifications for the parties. Contract modifications may terminate important rights afforded under the original agreement or add new substantial duties, which cannot be withdrawn unilaterally. ${ }^{78}$ In addition, modifying a contract in writing allows the parties to refer back to the documented modifications in order to accurately and efficiently perform the modification after it was made. ${ }^{79}$ Such written reference points might be particu-

excludes modification or rescission except by a signed writing cannot be otherwise modified or rescinded ....").

75. Cf. The Interpretation of International Contracts and the Use of Preambles, supra note 67, at 273 (stating that the chances that a NOM clause will be enforced by US courts "is clearly sufficient to merit the inclusion of such a clause."); Schwartz \& Scott, supra note 37, at 592 (arguing that an inference that the parties want modifications to be written is compelling "when the contract contains a term requiring modifications to be in writing.").

76. For the theoretical debate over the desirability of the course of performance doctrine, see Part II supra.

77. For a description of the systematic evaluation process potentially conducted by sophisticated parties before making a contractual change see, for example, INT'L Ass'N FOR CONTRACT \& Commercial Mgmt., Contract \& Commercial Management-The Operational Guide 570-71 (2011) [hereinafter The Operational Guide].

78. See supra text accompanying notes $12,13,15$.

79. Gregory A. Garrett \& Rene G. Rendon, The Contract Changes Management Process: Managing and Controlling Contract Changes, Cont. Mgmt. 54, 59 (October 2012) [hereinafter The Contract Changes Management Process] ("A formal contract changes management process and related documentation are essential elements of . . ensuring successful performance results such as: [o]n-time delivery; [o]n-budget completion of the work; and [q]uality products, services, and systems provided to the customer."); see also J. Timothy Sprehe, The Positive Benefits of Electronic Records Management in the Context of Enterprise Content Management, 22 Gov. INF. 
larly beneficial for sophisticated parties who enter into many complex commercial contracts, ${ }^{80}$ as these may have undergone many modifications throughout their long-term life cycles. ${ }^{81}$

Likewise, written contract modifications can help the members of each party to refer back to the documented modifications in order to monitor the performance of the contractual modifications by the other party. ${ }^{82}$ Moreover, the documentation of contract modifications in writing can assist sophisticated parties in ex post evaluation of whether their past modifications were efficient or wasteful. ${ }^{83}$ In addition, notice of written contractual modifications can be easily sent to relevant stakeholders, such as shareholders, company directors, and investors, ${ }^{84}$ as opposed to a non-written course of performance. Written contractual changes may also aid sophisticated parties in obtaining loans from banks, since banks may decide whether to approve loans based on written and updated contracts between the parties. ${ }^{85}$

Q. 297, 298 (2005) ("Records ensure that an enterprise can . . conduct its business in an orderly, efficient and accountable manner ....").

80. Jason Scott Johnston, Statutes of Frauds, in 3 The New Palgrave Dictionary of EcoNOMICS AND LAw 530, 532 (Peter Newman ed., 1998) ("[I]n a large business with many, complex contractual relationships, it would simply be impossible to perform efficiently without some record of what had been promised."); see also Small Business Administration, Record Keeping for a Small Business 6, https://www.sba.gov/sites/default/files/files/PARTICIPANT_GUIDE_REC ORD_KEEPING.pdf (last visited Oct. 12, 2018) ("Without a proper record keeping system, tracking important details of your business may be impossible.").

81. The Operational Guide, supra note 77, at 561 ("[W]here a project extends over a long period of time, change is inevitable. Static conditions are very rare . . ."); Gregory A. GARRett, Managing Contract Changes 3 (2013) [hereinafter Garrett] ("Change is inevitable in contract and project management.").

82. The Contract Changes Management Process, supra note 79, at 58 ("For the contract changes process, contract administration ensures that the new effort reflected in the contract change is performed by the contractor in accordance with the revised contract requirements.").

83. Dep’t of Treasury, Starting a Business and Keeping Records 11 (Jan. 14, 2015), https:// www.irs.gov/pub/irs-pdf/p583.pdf ("Records can show whether your business is improving, which items are selling, or what changes you need to make."); The Operational Guide, supra note 77 , at 564 (explaining that contract managers are advised to "[m]ake sure [their contract] change control process reviews this type of change periodically to ensure [they] are not suffering cumulative effects ....").

84. See, e.g., Elizabeth Shepherd, Why Are Records in the Public Sector Organizational Assets?, 16 Records MGMt. J. 6, 11 (2006) (stating that effective record management protects "the interests and rights of stakeholders . . ."); Sprehe, supra note 79, at 298 ("Records ensure that an enterprise can . . . document its policies, decisions, and outcomes to stakeholders ...."); Record Keeping Guidance, OECD CTR. FOR TAx POLICY \& ADMIN. 7, https://www.oecd.org/ctp/ administration/31663114.pdf (last visited Oct. 12, 2018) (explaining that keeping records allows businesses to "satisfy external auditors, company directors, shareholders, creditors, investors and other interested stakeholders that the records reflect a true and fair value of the business").

85. Record Keeping Guidance, supra note 84, at 7 ("On the basis of the financial documents and statements . . . banks decide whether to provide loans or other financial means ...."). 
Written contract modifications can also help the parties to protect themselves against lawsuits. ${ }^{86}$ Such documentation provides evidence about the implementation and contents of a contractual modification. ${ }^{87}$ Therefore, it may reduce the probability that a party will falsely testify in court that the parties modified the contract through their conduct. ${ }^{88}$ In the same vein, written modifications-by serving as formal evidence - can assist a party to secure its legal rights and file a lawsuit against a party who breached a documented modification. ${ }^{89}$ Lastly, the written modification can help the parties to settle disputes out of court. ${ }^{90}$ An absence of a written record complicates litigation, as memories regarding past conduct may fade, and some employees involved in the conduct may now be former employees. ${ }^{91}$

Given the significant benefits of modifying contracts in writing, it is not surprising that the contract management literature recommends

86. See e.g., Karen L. Sampson, Value-Added Records Management 11 (2d ed. 2002) (explaining that a written agreement may "help reduce the risk of being sued"); Sprehe, supra note 79, at 298 ("Records ensure that an enterprise can . . protect itself in litigation ...."); see also Lydon v. Nationwide Mut. Ins. Co., No. 91-11971-NG, 1997 WL 260064, at *9 (D. Mass. May 9, 1997) ("[N]o oral modification clauses have a valid business purpose, to the extent they serve to reduce legitimate uncertainty about such fertile grounds for dispute as whether the parties intended to bind themselves to a modification of some kind; what the precise terms of the modification were; and whether the party who purported to approve the purported modification had actual authority to do so.").

87. See, e.g., The Operational Guide, supra note 77, at 398 ("Most sales employees understand the value of having a written document describing the business deal so that clear evidence of the deal and its terms is available if a dispute arises."); see also Robert A. Hillman, Standards for Revising Article 2 of the UCC: The NOM Clause Model, 35 WM. \& MARy L. Rev. 1509, 1523 (1994) [hereinafter Hillman, Standards for Revising Article 2 of the UCC]; Shepherd, supra note 84 , at 4 ("[A] failure to create adequate records . . . may have more serious consequences. The organization may be unable to prove that it did what it was supposed to do . . . ; it may be unable to defend itself if liability claims are made against its services or the actions of its employees ....").

88. See e.g., Wis. Knife Works v. Nat'l Metal Crafters, 781 F.2d 1280, 1287 (7th Cir. 1986) (Judge Posner explains that " $[\mathrm{t}]$ he main purpose of forbidding oral modifications is to prevent the promisor from fabricating a modification that will let him escape his obligations under the contract . . . ."); see also Article 29(2) of the United Nations Convention on Contracts for the International Sale of Goods, supra note 71, at 450 (stating that parties include a NOM clause in order to "prevent fraudulent or mistaken claims of modification of a written agreement."); Hillman, Standards for Revising Article 2 of the UCC, supra note 87.

89. See e.g., Shepherd, supra note 84 , at 4 ("[A] failure to create adequate records . . may have more serious consequences. The organization may . . be unable to prove its rights . ...").

90. SAMPSON, supra note 86, at 11 (stating that a written agreement may "help persuade a plaintiff to drop a lawsuit ....”).

91. The Operational Guide, supra note 77, at 564 (2014) ("Even if it is agreed that a [contract] change has no visible effect on the contract terms it should still be recorded . . ; otherwise it might become later a source of dispute . . ."); Melissa Dewey Brumback, Managing Contract Change 5 (2006), http://ddryy2o5sc51c.cloudfront.net/wp-content/uploads/2013/02/MANAGING .pdf ("Avoid oral change orders if at all possible. Memories fade. People leave. Once any litigation occurs, you can guarantee that many of those oral conversations will be in hot dispute."). 
documenting contract modifications in writing. ${ }^{92}$ This Article therefore hypothesizes that commercial contracts between sophisticated parties will typically include a NOM clause, requiring contract modifications to be made only in writing.

In addition, this Article hypothesizes that contracts that include other "in-writing" clauses are more likely to include a NOM clause. In-writing clauses, as defined in this Article, are contractual clauses that require post-contractual actions of the parties, other than contract modification, to be made in writing. Relatively common examples of in-writing clauses are: (1) an anti-waiver clause, which states that any waiver of contractual obligations must be made in writing; (2) an anti-assignment clause, under which neither party may assign its contractual rights or obligations without the other party's written consent; and (3) a notices clause, which states that all notices under the agreement shall be in writing.

Given their nature, in-writing clauses reflect the parties' preference for written recordkeeping of all post-contractual actions, such as waiver, assignment, or notice. This Article assumes that if the parties indicate their preference for writing by utilizing in-writing clauses, they are more likely to utilize a NOM clause in their contract. This is because a NOM clause supports the parties' existing preferences for written recordkeeping, as reflected in the in-writing clauses. This Article proposes four hypotheses.

Hypothesis One $\left(\mathrm{H}_{1}\right)$ : A NOM clause is more likely than not to appear in commercial contracts between sophisticated parties.

92. GARrett, supra note 81, at 32 ("Document and execute all contract changes through formal modifications to the contract."); InT'L Ass'N FOr Contract \& COMMERcial Mgmt, Fundamentals of Contract and Commercial Management 249 (2013) ("Even if it is agreed that a change has no visible effect on the contract terms it should still be recorded ...."); The Operational Guide, supra note 77, at 572 ("Ensure the [contract] change records all aspects of the changes to the contract. These should be drafted . . . between the customer and the supplier and identify the specific change(s) in the contract wording to ensure there is always an up to date version of the contract avoiding the possible misunderstanding[s] . ..."); The Contract Changes Management Process, supra note 79, at 61 ("Formally approved changes to the project should be in writing ...."); GARRETT, supra note 81, at 51 ("Any change to a contract should be executed through a formal contract modification process and documented appropriately."); see also, Community Services Contract Management Practice Guide, Gov'T W. AustL. 25 (July 2016), http://www.finance.wa.gov.au/cms/uploadedFiles/Government_Procurement/Guidelines_and_templates/Community_Services_Templates_and_Guides/cs_contract_management_ practice_guide.pdf ("[S]ervice agreement managers should ensure that any proposed changes to a service agreement are managed in accordance with formal procedures as follows . . . each step of the action taken is recorded, with any changes incorporated in the service agreement by a formal variation to the original . . . ."); Contract Management Guidelines, MAV ProcuremenT 20, http://www.mav.asn.au/what-we-do/procurement/resources (last visited Oct. 12, 2018) ("Key issues to consider when managing contract variations include ... [p]roperly documenting details of the variation ...."). 
Hypothesis Two $\left(\mathrm{H}_{2}\right)$ : Contracts that include an anti-waiver clause are more likely to include a NOM clause than contracts without an anti-waiver clause.

Hypothesis Three $\left(\mathrm{H}_{3}\right)$ : Contracts that include an anti-assignment clause are more likely to include a NOM clause than contracts without an anti-assignment clause.

Hypothesis Four $\left(\mathrm{H}_{4}\right)$ : Contracts that include a notices clause are more likely to include a NOM clause than contracts without a notices clause.

\section{Data}

The sample of this empirical study is based on commercial contracts included as exhibits to filings with the SEC. ${ }^{93}$ This study covers a fiveyear period from January 1, 2013 to January 1, 2018. The resulting final sample comprises 1,550 commercial contracts. These contracts were located via Westlaw's commercial law sample-agreement search engine. ${ }^{94}$ The Westlaw sample-agreements database has contracts included in all SEC filings during the sample period. 95

The contracts analyzed in this study particularly survey Form 8-K filings with the SEC. Form 8-K includes information which is consid-

93. For the same methodological approach of analyzing contracts contained as exhibits to Form 8-K filings with the SEC, see Theodore Eisenberg, Geoffrey P. Miller, \& Emily Sherwin, Arbitration's Summer Soldiers: An Empirical Study of Arbitration Clauses in Consumer and Nonconsumer Contracts, 41 U. Mich. J.L. REFORM 871, 880 (2008); Theodore Eisenberg \& Geoffrey P. Miller, Damages Versus Specific Performance: Lessons from Commercial Contracts, 12 J. EMPIRICAl Legal STud. 29, 43 (2015) [hereinafter Eisenberg \& Miller, Damages Versus Specific Performance]; Theodore Eisenberg \& Geoffrey P. Miller, Do Juries Add Value? Evidence from an Empirical Study of Jury Trial Waiver Clauses in Large Corporate Contracts, 4 J. EMPIRICAL Legal Stud. 539, 550 (2007) [hereinafter Eisenberg \& Miller, Do Juries Add Value?]; Theodore Eisenberg \& Geoffrey P. Miller, The English Versus the American Rule on Attorney Fees: An Empirical Study of Public Company Contracts, 98 Connell L. Rev. 327, 349 (2013); Theodore Eisenberg \& Geoffrey Miller, Ex Ante Choices of Law and Forum: An Empirical Analysis of Corporate Merger Agreements, 59 VAnd. L. Rev. 1975, 1983 (2006); Theodore Eisenberg \& Geoffrey P. Miller, The Flight from Arbitration: An Empirical Study of Ex Ante Arbitration Clauses in the Contracts of Publicly Held Companies, 56 DePAul L. REv. 335, 348 (2007) [hereinafter Eisenberg \& Miller, The Flight from Arbitration]; Theodore Eisenberg \& Geoffrey P. Miller, The Flight to New York: An Empirical Study of Choice of Law and Choice of Forum Clauses in Publicly-Held Companies' Contracts, 30 CARdozo L. REv. 1475, 1487 (2009).

94. In order to exclude contracts that were merely an amendment to a contract, I searched via Westlaw's search engine only for contracts that included in their title the following terms: (agreement! or contract!) \% amendment!. The "!" symbol was used to search for words with multiple endings, and the "\%" symbol was used to exclude the term following the percent symbol. See WESTLAw, https://lawschool.westlaw.com/marketing/display/RE/152 (last visited Dec. 10, 2017) [hereinafter Terms and Connectors Searches]. I also excluded exhibits that were apparently duplicates, as witnessed by their title and date.

95. Sample Agreements, Thomson Reuters, http://legalsolutions.thomsonreuters.com/lawproducts/westlaw-legal-research/transactions/sample-agreements (last visited Jan. 1, 2018). 
ered to be material. ${ }^{96}$ Generally put, a reasonable investor is likely to consider material obligations and rights to be "important in making an investment decision." 97 This information must specifically include the entry of the company into a "material definitive agreement." 98 This agreement provides for obligations or rights that are material to the filing company. ${ }^{99}$

The commercial contracts examined in this study are highly heterogeneous and include the following: distribution, agency, consulting, management services, cooperation, independent contractor, marketing, licensing, financing, and manufacturing agreements. ${ }^{100}$ The major types of contracts, as reflected in the contracts' titles, are shown in Table 1.

96. Investor Bulletin: How to Read an 8-K, U.S. SEC. \& ExCH. COMM'N: SEC OfFICE OF InV'R Educ. \& Advocacy (May 22, 2012), https://www.sec.gov/investor/pubs/readan8k.pdf.

97. How to Read an 8-K, Investor.GOv (May 22, 2012), https://www.investor.gov/additionalresources/news-alerts/alerts-bulletins/how-read-8-k.

98. Id.

99. Id.

100. A commercial contract, as opposed to a consumer or employment contract, is typically an agreement between two or more business entities. See Schwartz \& Scott, supra note 37, at 543 ("Even a theory of contract law that focuses only on the enforcement of bargains must still consider the entire continuum from standard form contracts between firms and consumers to commercial contracts among businesses.”); Edward A. Zelinsky, Deregulating Marriage: The Pro-Marriage Case for Abolishing Civil Marriage, 27 CARdozo L. Rev. 1161, 1198 (2006) ("Consumer contracts differ from commercial contracts between businesses."); see also Joshua M. Silverstein, Using the West Key Number System as a Data Collection and Coding Device for Empirical Legal Scholarship: Demonstrating the Method Via a Study of Contract Interpretation, 34 J.L. \& COM. 203, 261 (2016). 
Table 1. Number and percentage of contracts by type.

\begin{tabular}{|c|c|c|}
\hline Type & Number $^{101}$ & Percentage $^{102}$ \\
\hline Distribution & 176 & 11.35 \\
\hline $\begin{array}{c}\text { Consulting or } \\
\text { Advisory }\end{array}$ & 159 & 10.26 \\
\hline Agency & 133 & 8.58 \\
\hline $\begin{array}{c}\text { Management } \\
\text { Services }\end{array}$ & 133 & 8.58 \\
\hline $\begin{array}{c}\text { Cooperation } \\
\text { Marketing }\end{array}$ & 124 & 8 \\
\hline $\begin{array}{c}\text { Independent } \\
\text { Contractor }\end{array}$ & 63 & 4.06 \\
\hline Licensing & 57 & 3.68 \\
\hline Development & 41 & 2.65 \\
\hline Manufacturing & 40 & 2.58 \\
\hline Financing & 40 & 2.58 \\
\hline
\end{tabular}

\begin{tabular}{|c|c|c|}
\hline Type & Number & Percentage \\
\hline $\begin{array}{c}\text { Terminal } \\
\text { Services }\end{array}$ & 28 & 1.81 \\
\hline Supply & 28 & 1.81 \\
\hline $\begin{array}{c}\text { Administrative } \\
\text { Services }\end{array}$ & 27 & 1.74 \\
\hline Purchase & 25 & 1.61 \\
\hline $\begin{array}{c}\text { Exporter } \\
\text { Services }\end{array}$ & 21 & 1.35 \\
\hline $\begin{array}{c}\text { Transportation } \\
\text { Services }\end{array}$ & 19 & 1.23 \\
\hline Storage & 17 & 1.10 \\
\hline Research & 9 & 0.58 \\
\hline Advertising & 7 & 0.45 \\
\hline Assignment & 4 & 0.26 \\
\hline $\begin{array}{c}\text { Pipeline } \\
\text { Services }\end{array}$ & 2 & 0.13 \\
\hline
\end{tabular}

The industries of the companies that filed these contracts with the SEC are also heterogeneous and include the following: advertising, agriculture, banking, beverage, biological products, business services, cosmetic, electricity, hotels and motels, management services, medical instruments, metal mining, patents, pharmaceutical, real estate, restaurant, software, television, transportation, and wholesale. ${ }^{103}$

\section{Methodology}

In order to locate contracts with a NOM clause, I took the following main steps: First, I conducted an in-depth review of the full text of 100 random commercial contracts in the sample. The purpose of this review was to identify the terms commonly associated with a NOM clause. Second, based on my in-depth review I conducted an online search, using Westlaw's Terms and Connectors search engine, for con-

101. Number of contracts by contract type (sample size $n=1,550$ ).

102. Percentage of contracts by contract type (sample size $n=1,550$ ).

103. The companies industries were located via the EDGAR company search engine. See EDGAR: Company Filings, U.S. SEC. \& ExсH. CoMm'N, https://www.sec.gov/edgar/searchedgar/ companysearch.html (last visited Jan. 1, 2018). 
tracts containing terms commonly associated with a NOM clause. ${ }^{104}$ This search included the following terms: ("modif! /s writ!") or ("amend! /s writ!"). ${ }^{105}$ The "!" symbol was used to search for words with multiple endings, and the "/s" symbol was used to search for terms in the same sentence. ${ }^{106}$ Contracts with a NOM clause were coded "1." Finally, in order to verify that the search results for terms commonly associated with a NOM clause were not overinclusive, I manually coded an audit of 100 random contracts which were coded "1." The audit was successful.107

In order to locate contracts with in-writing clauses, I took the following steps for each type of in-writing clause: First, I conducted an in-depth review of the full text of 100 random commercial contracts in the sample in order to identify the terms commonly associated with inwriting clauses. Second, based on this review, I conducted an online search, using Westlaw's Terms and Connectors search engine, for contracts containing terms commonly associated with in-writing clauses. For example, to determine whether a contract included an anti-assignment clause, which requires written consent for an assignment, I searched via Westlaw's Terms and Connectors search engine for the term "assign! /s writ! /s consent."108 Contracts with an in-writing clause were coded " 1. ."

Finally, in order to verify that my search results for terms commonly associated with in-writing clauses were not overinclusive, I manually coded an audit of 100 random contracts which were coded "1." The audit was successful. ${ }^{109}$

\section{E. Results}

Out of 1,550 contracts, 1,241 $(80.06 \%)$ included a NOM clause and $309(19.94 \%)$ did not include a NOM clause. An exact Fisher test was

104. For a similar methodological approach applied on a "specific performance" clause, see Eisenberg \& Miller, Damages Versus Specific Performance, supra note 93, at 44.

105. I also searched, via Westlaw's "Clause Title" search function, for contracts with the following clause titles: "modification!" and "amendment!".

106. Terms and Connectors Searches, supra note 94.

107. Out of 100 results, no result was overinclusive.

108. For all other in-writing clauses, my search included the following terms: "waiv! /s writ!"; "notices /s 'in writ!'”; and “"any notice'/s writ!". I also searched, via Westlaw's "Clause Title" search function, for contracts with the title "notices", in order to locate additional notices clauses.

109. Out of 100 results, only $2(2 \%)$ were overinclusive. 
performed, 110 and it was statistically found that a NOM clause appears significantly more often than not $(p<0.001),{ }^{111}$ thus supporting $\mathrm{H}_{1} \cdot{ }^{112}$

The results also support $\mathrm{H}_{2}-\mathrm{H}_{4}{ }^{113}$ Table 2 shows the frequency and percentage of contracts with and without a NOM clause for each inwriting clause. In order to test for $\mathrm{H}_{2}-\mathrm{H}_{4}$, a basic exact Fisher test was performed. It showed a significant statistical relationship between each of the explanatory variables (the anti-waiver, anti-assignment, and notices clauses) and the outcome variable NOM clause $(p<0.001$ for all three explanatory variables).

Table 2. Cross tabulation of a NOM clause and other in-writing clauses.

\begin{tabular}{|l|l|l|l|l|l|}
\hline \multirow{2}{*}{ Clause Type in Contract } & \multirow{2}{*}{ Total } & \multicolumn{2}{l|}{ With NOM Clause } & \multicolumn{2}{l|}{ Without NOM Clause } \\
\cline { 3 - 6 } & & Number & Percentage & Number & Percentage \\
\hline Anti-Waiver Clause & 692 & 676 & 97.69 & 16 & 2.31 \\
\hline No Anti-Waiver Clause & 858 & 565 & 65.85 & 293 & 34.15 \\
\hline Anti-Assignment Clause & 653 & 624 & 95.56 & 29 & 4.44 \\
\hline $\begin{array}{l}\text { Without Anti-Assignment } \\
\text { Clause }\end{array}$ & 897 & 617 & 68.78 & 280 & 31.22 \\
\hline Notices Clause & 1163 & 028 & 88.39 & 135 & 11.61 \\
\hline Without Notices Clause & 387 & 213 & 55.04 & 174 & 44.96 \\
\hline
\end{tabular}

In addition, the results of logistic regression models-with a NOM clause as the outcome variable and the anti-waiver, anti-assignment, and notices clauses as the explanatory variables-were examined. First, I constructed a univariate model to test hypotheses $\mathrm{H}_{2}-\mathrm{H}_{4}$ and to obtain crude odds ratios (OR), ${ }^{114}$ and respective $95 \%$ confidence intervals (CI). I found that a contract with an anti-waiver clause was

110. This test is used to examine whether there is a nonrandom association between two categorical variables. See Eric W. Weisstein, Fisher's Exact Test, Wolfram MathWorld, http:// mathworld.wolfram.com/FishersExactTest.html (last visited Oct. 12, 2018).

111. The P-value $(p)$ signifies the likelihood of obtaining an effect equal to or more extreme than the one observed, assuming the null hypothesis is true. See David Jean Biau et al., $P$ Value and the Theory of Hypothesis Testing, 468 Clinic Orthopedic \& Related Res. 885, 886 (2010). The smaller the P-value, the more doubtful the null hypothesis is. Id.

112. See supra Part III.B ("Hypothesis One (H1): A NOM clause is more likely than not to appear in commercial contracts between sophisticated parties.").

113. See supra Part III.B ("Hypothesis Two (H2): Contracts that include an anti-waiver clause are more likely to include a NOM clause than contracts without an anti-waiver clause. Hypothesis Three (H3): Contracts that include an anti-assignment clause are more likely to include a NOM clause than contracts without an anti-assignment clause. Hypothesis Four (H4): Contracts that include a notices clause are more likely to include a NOM clause than contracts without a notices clause.").

114. The OR signifies the odds that an outcome will happen given a specific exposure, compared to the odds of that outcome happening without the same exposure. See, Magdalena Szumi- 
associated with 21.9 (95\% CI: 13.5, 38.2) greater odds of including a NOM clause; the ORs and 95\% CIs for anti-assignment and notices clauses were $9.8(6.7,14.8)$ and $6.2(4.8,8.2)$, respectively $(p<0.001$ for all three tests). These results are indicated in Table $3 . \mathrm{H}_{2}-\mathrm{H}_{4}$ are therefore supported. ${ }^{115}$ In addition, an additive multivariate model was fitted containing all three clauses-anti-waiver, anti-assignment and notices-additively in the model. The results in Table 3 indicate some effect attenuation for all clauses, but all estimates are still highly significant $(p<0.001)$.

Table 3. Results of univariate and additive logistic regression models.

\begin{tabular}{|l|l|l|l|l|}
\hline \multicolumn{4}{|c|}{ Univariate models } & $\begin{array}{l}\text { Multivariate } \\
\text { additive model }\end{array}$ \\
\cline { 1 - 4 } Effect & $\begin{array}{l}\text { NOM clause } \\
\text { model }\end{array}$ & $\begin{array}{l}\text { Anti-waiver } \\
\text { clause model }\end{array}$ & $\begin{array}{l}\text { Anti-assignment } \\
\text { clause model }\end{array}$ & \\
\hline Anti-Waiver & $21.9(13.5,38.2)$ & - & - & $\begin{array}{l}11.2 \\
(6.8,19.8)\end{array}$ \\
\hline Anti-Assignment & - & $9.8(6.7,14.8)$ & - & $\begin{array}{l}4.4 \\
(2.9,6.8)\end{array}$ \\
\hline Notices & - & - & $6.2(4.8,8.2)$ & $\begin{array}{l}3.2 \\
(2.4,4.3)\end{array}$ \\
\hline
\end{tabular}

$\underline{\text { Notes: }}$ All estimates are statistically significant $(p<0.001), N=1550$. Crude odd rate (OR) and confidence interval (CI) at $95 \%$.

\section{Discussion and Normative Implications}

The results of this empirical study indicate that most sophisticated parties to commercial contracts resent the course of performance doctrine. The study shows that a clear majority $(80.06 \%)$ of commercial contracts filed with the SEC have a NOM clause, requiring modifications of the contract to be made only in writing.

One major legal implication of these results is the need to modify the default modification rules currently governing commercial contracts between sophisticated parties. Due to the fact that most of these contracts contain a NOM clause, the default rules should align with the majority's preferences. Specifically, the default rules should mandate that modifications to commercial contracts must be made only in

las, Explaining Odds Ratios, 19 J. Can. Acad. Child Adolescent Psychiatry 227, 227 (2010).

115. In addition, a basic exact Fisher test was performed. It also showed a statistical relationship between each of the explanatory variables (anti-waiver, anti-assignment, and notices clause) and the outcome variable NOM clause $(\mathrm{P}<0.001$ for all three explanatory variables). 
writing, while also prohibiting any and all modifications by way of non-written course of performance.

Those desiring to opt out from the new default modification rules presented are the minority of parties to such contracts. By mirroring the majority's preferences, the law would reduce the financial expenditure of most sophisticated parties on transaction costs associated with commercial contracts. This would, in turn, create a system where only the minority will have to negotiate and draft anti-NOM clauses that state inter alia, that the contract "may be modified by non-written course of performance." Such an innovative legal reality will reduce transaction costs for most parties, as they will no longer have to negotiate and draft NOM clauses.

One could argue that the results of this study are severely limited if the NOM clauses in the sample are mere boilerplates, i.e., the NOM clauses in the sample contracts were included by the parties without any actual intent. There are several reasons why this is an unlikely scenario.

First, the sample used in this empirical study comprises contracts included as exhibits to Form 8-K filings with the SEC. Companies file the Form 8-K to report material corporate events, a subset of which is "material definitive agreements." 116 Per the SEC, material definitive agreements are ones that provide for obligations or rights that are material to the SEC filing company. ${ }^{117}$ Since the contracts comprising the sample are material to the registrant, i.e., the filing company, it is likely "that they receive[d] care and attention during negotiation and drafting" from company employees, including in-house counsel, as well as qualified outside attorneys. ${ }^{118}$

Second, the sample in this study comprises only commercial contracts in which one of the parties is a sophisticated entity that is legally obligated to report to the SEC. These companies usually have more than $\$ 10$ million in assets and their securities are held by more than 500 owners. ${ }^{119}$ Given the level of screening and qualification standards required of sophisticated SEC filing companies, it is plausible that the counterparties to the sample commercial contracts included in this study are relatively sophisticated business entities as well. Crucially, this sample does not include commercial contracts between non-sophisticated parties nor non-commercial contracts, such as employment

116. How to Read an 8-K, supra note 97.

117. How to Read an 8-K, supra note 97.

118. Do Juries Add Value?, supra note 93, at 582; see also, The Flight from Arbitration, supra note 93 , at 349 .

119. See Securities Exchange Act of 1934 12(g), 15 U.S.C. § 781 (2012). 
and consumer agreements. By that the sample assures, with a potential slight margin of error, that the NOM clauses observed in this data set were understood and freely agreed on by both parties. ${ }^{120}$

Third, the empirical results obtained indicate that the NOM clauses included in the sample contracts are not random boilerplates. More specifically, the results show that contracts containing fundamental inwriting clauses, such as an anti-waiver clause, an anti-assignment clause, and a notices clause, are significantly more likely to include a NOM clause than contracts without such in-writing clauses. ${ }^{121}$

\section{CONCLUSION}

This Article empirically examines the frequency with which anticourse of performance clauses are included in commercial contracts between sophisticated parties. This Article empirically demonstrates, by analyzing actual commercial contracts, that sophisticated parties to commercial contracts are likely to resent the application of the course of performance doctrine by the courts. The study further shows that the inclusion of an anti-course of performance clause by most parties is not arbitrary. The inclusion of clauses that are related to an anticourse of performance clause, such as anti-waiver, anti-assignment, or notices clauses, is significantly associated with the inclusion of an anticourse of performance clause.

While this study focuses on commercial contracts between sophisticated entities, there is room for further empirical research on the intentions of the parties regarding the course of performance doctrine. This study can be expanded upon by empirically investigating the preferences of non-sophisticated parties to commercial contracts and to non-commercial contracts.

120. Damages Versus Specific Performance, supra note 93, at 31.

121. See supra Part III.E. 